\title{
BANKING COMPANY: DUE LEGAL PROCEDURE OF MERGERS \& ACQUISITIONS IN INDIA
}

\author{
Dr. Atal Kumar \\ Associate Professor Mewar Law Institute, Ghaziabad, UP-201010 \\ DOI: 10.46609/IJSSER.2020.v05i10.031 URL: https://doi.org/10.46609/IJSSER.2020.v05i10.031
}

\begin{abstract}
The Banking Structure is the primary element of any country's economy. Development and advancement in the banking area prompt the advance of the other corporate sectors. Our Banking sector is accomplishing constant development which is one of the utmost astonishing features.

The commitment of the Banks in setting up and also keeping up a global economic status is important. Several transformations familiarized after nationalization like private banking had a noteworthy impact on the overall banking scenario in the nation. The development in the quantity of private banks and the accessible opportunity for banking organizations in the nation has likewise influenced the way business is directed all-inclusive clearing path for Foreign Private Banks additionally to enter in India.

Indian Financial institutions are intermediaries that mobilize savings and facilitate allocation of funds in an efficient manner. The Indian financial system was quite well developed even prior to India's political independence in August 1947. Both foreign and domestic banks were present and so was a well-developed stock market.
\end{abstract}

\section{Introduction of Banking Mergers \& Acquisitions}

Over the years after accepting the recommendations of Narsimham Committee, Verma Committee and several other committees Indian Banking sector has brought up all the desired characteristics of model banking system. But Indian banking system is still perceived as high cost banking as operating cost in India is around 2.3 per cent against 1.1 per cent in China, 1.6 per cent in Malaysia, 2.1 per cent in European Countries. Another key issue that needs to be addressed cautiously is the increase in the NPAs. Apart from absolute size, the distribution of NPAs is skewed across banks. The Narsimham Committee has underlined the need to reduce the average level of net NPAs for all banks to 3 per cent by 2002 and zero for banks with international presence. However, it has come down to 1.9 as was recommended by committee. 
International Journal of Social Science and Economic Research

ISSN: 2455-8834

Volume:05, Issue:10 "October 2020"

The Government of India accepted all the major recommendations of the Narasimham Committee-1991 and started the process of implementation on urgent basis.

\section{Following various committees gave suggestions for handling finance and banking issues}

○ Narashiman Committee

- Chakravarty Committee

○ Shroff committee

J.J. Irani committee

\section{The above committee suggested in 1991}

There ought to be limited banks however solid bank which can stand globally, universally and other little banks ought to be locale particular and country territory particular.

Further in 1998, report was about the consolidation of banking in light of developed anxiety circumstance in banking sector and the need of M\&A between NBFC, feeble banks with strong banks which can advance their circumstance and also ask to handle about the relevant group of people who are going to be affected by the M\&A like shareholders, the stakeholders, employees, role of government policies and rules and regulation of the authority.

Other committee said about the rights and roles of RBI, it recommended that RBI should play a very active role for the process of M\&A. specifically about the share swap ratio, single stop concept, valuation for merger deal and process.

There are many critical issues which should be resolved on priority basis like a forced merger, after merger effects or side effects due to miscalculation of valuation of the intangible assets like intellectual property i.e. brand value, goodwill and efficient staff, superior technology etc. along with ATM numbers.

Till 2000, RBI forced the merger of weak private sector banks with public sector banks, the resolution taken as corrective measures and with the intention to manage economic collapse and protect customer's deposits and trust. But the forced merger never figured out any analysis or say there are no calculations of risk which lead to adverse effect on the capital ratio of the merged bank.

After the committee reviewed the consequences and found that merger of strong banks with weaker banks are not providing any benefit. Their assumption was that it can help the weaker bank, but it was the nastiest decision, practically it gives no benefits to anyone rather gives negative impact to strong banks by increasing their NPA and liabilities. 
International Journal of Social Science and Economic Research

ISSN: $2455-8834$

Volume:05, Issue:10 "October 2020"

$\mathrm{RBI}$ is the greater and central authority for Banking Merger and plays very core role along with the high court's so proper and firm guidelines should be there in order to reduce workload and enhance concentration on necessary points Irani committee gave suggestion to fix the problem which is as follows:

○ There should be an independent valuer.

- There should be single window concept

- Proper clauses should be there,

However, no ground work is done on this by RBI.

The forced merger does not give any material benefits to the banks, it only gives one benefit i.e. tax profits for the Acquiree bank. It shows that there was no business motive involved in the merger, the only motive was to save tax by showing more losses which come with merging bank. This opportunity was given to them by the RBI by forcing the merger on them and this satisfied their malicious intentions.

After all the recommendation of various committees, there is still need for improvement and responsible authority like the expert panel or Bank Board for Consolidation should be set up. The outcome of banking merger is a good sign of improvement of the sector but not up to the mark. Many initiatives have been taken by RBI and Government with the intention of making strong banks capable to compete globally.

Narashiman committee recommends that there is no need for small and more banks but there should be few big and strong banks which can compete internationally and cope up with global scenario. This resulted in the SBI merger with its subsidiaries and BMB and the combined entity entered into the list of the world's top 50 banks in terms of assets.

\section{Definition of Banking Company}

Banking company as per Sec. 5 (C) of the B R Act 1949 defines a Banking Company. "which means any company transacts the business of banking in India" which excludes the company carries any trade and accepts deposits of money from the public.

In fact, UK law also mentions the same; no company could accept deposit from members of the public unless it is company governed by the banking law of that country.

\section{Bank Merger Regulation}

The provision of Banking Regulation Act 1949 in derogation of the Companies Act, 2013 or any other law for time being in force. As per Sec 44A of the Banking Regulation Act 1949, the 


\section{International Journal of Social Science and Economic Research}

ISSN: $2455-8834$

Volume:05, Issue:10 "October 2020"

draft of procedures of amalgamation has to be approved by the shareholders of each banking company by a resolution passed by a majority in number representing $2 / 3 \mathrm{rd}$ in the value of the shareholders, present in person or by proxy at a meeting called for the purpose. The approval of the Reserve Bank of India is also needed. Such companies do not need to go to the National Company Law Tribunal (NCLT).

As per, NBFC (Deposit Accepting) (Approval of Acquisition or Transfer of Control) Directions, 2009, any takeover or acquisition of control of a deposittaking NBFC, whether by acquisition of shares or otherwise, or any merger/amalgamation of a deposit-taking NBFC with another entity, shall be mandatory to have prior written approval or permission of R B I.

In the case of non- banking financial companies, whenever there is any kind of change of control by acquisition or transfer of shares or change in the ultimate holding company, the same would need the approval of the RBI.

Without prejudice to the generality of Sec. 396, it has now been notified and proclaimed by the MCA that, in appropriate events, modest procedures shall be adopted for the amalgamation of Gov. Company under Sec. 396 of the Company Act, 1956.

Banking Company Inter Se and also for the amalgamation of Non-Banking Financial Company with a Banking company. It is the duty of the Reserve Bank of India to issue master circulars and directions each year. The Reserve Bank of India announces various policy decisions by circulars and also wherever legal prescription is required, the same is issued by way of directions and notifications. As there are frequently amendments made to such directions and notifications.

\section{Sanction by Reserve Bank of India}

1. If the scheme of consolidation should agree and approved by the required majority of shareholders in accordance with the laws and provisions applicable, it shall be submitted to the RBI for its approval.

2. The RBI may sanction a scheme through the written orders.

3. The scheme that is approved by the RBI will be obligatory authority on the banking co. concerned and also on all the shareholders of such company.

4. An order passed by the RBI in relation to approval of the scheme of amalgamation will be evidentiary conclusion that all the necessity of rules and regulations relating to amalgamation are obeyed with by the concerned parties.

5. All paper and proceeding shall be certify true copy by the officer of the RBI officer shall be admitted as a evidence in original scheme as well as in order.

\section{For the Amalgamation of NBFC with Banking Company}


Following approvals are required-
- Approval of BOD
O approval of shareholders
- approval of RBI
○ Confirmation of Tribunal.

For the Takeover of NBFC accepting deposits prior RBI approval required. Merger procedure will done same as Companies act.

\section{Reconstruction of Sick Banking Company}

Sec. 45 of Banking Regulation Act, the RBI approaches the Central government for the issue of an order for moratorium in respect of a banking company. After considering application and verification of the same by Central Government and if thinks fit and proper then Moratorium shall not exceed six months. This decision is taken by the RBI, in the public interest, to secure proper management of banking company and banking system of the country.

United Bank of India Ltd Vs. United India Credit and Development Co. Ltd. the scope of the jurisdiction of the High Court was formulated thus, the court cannot speculate at this as to the possibility, the potentiality of the amalgamated company in future and its working. It is true that the court is not a mere rubberstamp but in sound exercise of its discretionary power to sanction a scheme, must consider the scheme as a whole having regard to general conditions, background, an object of the scheme and the present day conditions, and atmosphere in the state where the companies are going to function.

The Court cannot take the pedantic and strict view of each and every clause in the scheme and speculate as to its future, feasibility, and possibility at this stage. It is for the collective wisdom of the shareholders who are primarily businessmen and investors guided by the directors of a company to determine the course of business they choose.

JX Holdings Inc. and another Vs. Singapore Airlines Ltd [2016] 5 SLR 988, where the Singapore High Court recognized the doctrine of universal succession in the context of a corporate restructuring of a Japanese company. In that case, the Singapore High Court recognized for the first time that the doctrine of universal succession applies in Singapore. It was held that the foreign banks i.e. France based bank in country's i.e. Singapore banking Act should follow respective country regulation but liberty also given to the foreign bank. So it doesn't create negative impact on future foreign investors.

\section{Observation \& conclusion}




\section{International Journal of Social Science and Economic Research}

ISSN: $2455-8834$

Volume:05, Issue:10 "October 2020"

In India many more mergers are expected in near future. In fact, government proclaimed their plans for further; however, there are many hurdles. Many experts and even banks are against this scheme. Former RBI governor

Raghuram Rajan in an interview to The Economic Times on 6th Sep'2017 said bank mergers would be a complex procedure."Consolidation itself requires a whole lot of time and effort by bank CEOs and bank managers throughout the system. You need to consolidate IT frameworks, you need to combine cultures, need to blend HR framework and so on that includes huge measures of work."which indicates RBI is as yet committing a similar error by blending feeble banks which ought to be avoided.

The merger of banks should between healthy banks only for that first step taken by the banks by correcting their balance sheet and making it healthy which can make bank strong. Further, he suggested, "There is need to create independent authority/body." RBI is not independent in the matter of regulation and has to work under government only. It cannot work in disagreement with the government which creates difficulty and cant correct loopholes of the banking regulations and the system. Those loopholes ill-used by big borrowers which affect badly to the Balance sheet of the banks and all over system and economy.

The intention of the government of expanding banks through merger has an important disadvantage. By merging a strong bank with a bank whose NPA is more, the government is increasing the liabilities of the strong bank. As a result, the strong bank becomes weaker. If the government continues this can be a disaster for our banking sector.

In other countries Banking sectors have different laws and banking regulations like our nation. Merger Procedures is mentioned in relevant authorities and acts mentioned in detail in the previous chapter. Financial consolidation has effects not only for competition but also for financial stability, monetary policy, the productivity of financial institutions, credit flows, and payment and settlement systems.

Given the diverse nature of financial institutions, different levels of financial development, legal framework and another enabling environment, the grounds and influence on fiscal consolidation have also inclined to vary across the countries. For instance, banking merger and amalgamation led to higher focus in countries such as US and Japan, though they endure to have much more competitive banking systems as compared with other countries. In any case, in a several nations, the procedure of consolidation led to diminishing in banking concentration, reflecting an increase in competition. This was fundamentally on the grounds that banks engaged with M\&As were of generally small in size. 